\title{
Morphology and palaeoecology of a new edrioblastoid from the Furongian of China
}

Xuejian Zhu, Samuel Zamora, and Bertrand Lefebvre

Acta Palaeontologica Polonica 59 (4), 2014: 921-926 doi: http://dx.doi.org/10.4202/app.2012.0116

A new edrioblastoid Cambroblastus guolensis is described from the Furongian (late Cambrian) Sandu Formation (South China). This represents the second occurrence of a Cambrian edrioblastoid, and the first ever reported from Asia, extending the palaeogeographic range of this very rare echinoderm grade. Surprisingly it preserves a complete stem and a distal holdfast suggesting edrioblastoids were hard substrate attachers living in soft bottom quiet environments.

Xuejian Zhu [xuejianzhu9@hotmail.com], Nanjing Institute of Geology and Palaeontology, Chinese Academy of Sciences, Nanjing 210008, China, and Department of Earth Sciences, Nanjing University, Nanjing 210093, China; Samuel Zamora [samuel@unizar.es], Department of Paleobiology, National Museum of Natural History, Smithsonian Institution, Washington DC, 20013-7012, USA (corresponding author); Bertrand Lefebvre [bertrand.lefebvre@univ-lyon1.fr], UMR CNRS 5276, Géode, Université Lyon 1, 2 rue Dubois, 69622 Villeurbanne cedex, France.

This is an open-access article distributed under the terms of the Creative Commons Attribution License (for details please see creativecommons.org), which permits unrestricted use, distribution, and reproduction in any medium, provided the original author and source are credited. 